\title{
Covid-19 and Other Viruses in Brazil: Can the New Pandemic Influence Epidemiological Records?
}

Haniel Soares Fernandes ${ }^{1}$

${ }^{1}$ Faculdade Estácio de Sá, Departamento de nutrição, Fortaleza, Ceará, Brasil

${ }^{1}$ Faculdade São Gabriel da Palha, Nutrição, metabolismo e fisiologia no esporte, Minas Gerais, Brasil

${ }^{1}$ Faculdade de Economia, Administração, Atuariais e Contábeis, Universidade Federal do Ceará, Fortaleza, Ceará, Brasil

${ }^{1}$ https://orcid.org/0000-0003-0971-482X

$\underline{{ }^{1} \text { Haniel_fernandes@ hotmail.com }}$

\begin{abstract}
Amid the covid-19 pandemic, other diseases, including viruses, are still acting to the detriment of their seasonality and risk factors for contagion. For this reason, it is interesting to know the degree of impact of other viruses, mainly respiratory, in which they have similar symptoms, in diagnoses for contamination by the new coronavirus based on epidemiological surveys, via epidemiological weeks, in Brazil. To what extent there may be a hypothesis of confusion of contaminated data, harming the health system, with regard to the need for intensive care units and control of viruses, and negatively or positively implying in the control or uncontrolling of viruses in general.
\end{abstract}

Keywords: covid-19; epidemiology; epidemiological week; Brazil; coronavirus; viruses

\section{Introduction}

Brazil has control of epidemiological data on the main diseases diagnosed in the country through the dissemination of weekly epidemiological bulletins, based on surveys by the Health Departments of each municipality to assess contagion projections by statistical calculations, culminating in the possible creation of health policies. public health determinants for each disease. However, with the arrival of the new coronavirus pandemic and all national precautions to avoid its peak of contagion, there may be conflicts in the health system due to the continued incidence of other viral diseases, especially respiratory diseases, in which they have symptoms similar to that cause by covid-19 (coronavirus desease 19). The hypothesis is that the new virus may be confusing the diagnosis of the other viruses and influencing the disclosures and projections of contagions. 


\section{The new coronavirus pandemic}

The infection by Sars-Cov-2 (Severe Acute Respiratory Syndrome Coronavirus 2), also known as Covid-19, started in mid-November 2019 in China and, spreading to other countries and continents, reached approximately 80 thousand confirmed cases until January this year, being declared a pandemic on March 11, 2020 by the World Health Organization (WHO) due to its high transmissibility power from human to human, where an infected person can transmit, on average, to six other individuals ${ }^{1}$.

\section{Other viral diseases amid the covid-19 pandemic in Brazil}

In addition, a recent study brought the alert from the Pan American Health Organization (PAHO / WHO) to the current scenario, including Brazil, regarding the possibility of a union, which would involve the pandemic of the new coronavirus and the increase of the incidence of arboviruses and respiratory diseases, including Dengue and Influenza, taking into account their seasonality, that is, the influence of the rainy season in the region ${ }^{2}$.

The Ministry of Health of Brazil publishes epidemiological bulletins of contagious diseases, as well as arboviruses (Dengue, Chikungunya and Zika), based on epidemiological weeks (SE) through data recorded every 2 weeks of the year. Up to SE 15 (from the beginning of the year to the second week of April), 90,855 probable dengue cases were reported in $2018^{3}, 451,685$ probable dengue cases in $2019^{4}$ and 557,750 probable dengue cases in $2020{ }^{5}$. Counting an increase, between the same periods, of approximately 397\% from 2018 to 2019 and $23 \%$ from 2019 to 2020, the latter already in the middle of the covid-19 pandemic ${ }^{1}$ and their respective social isolation measures in the country ${ }^{6}$ after almost 24 thousand confirmed cases in this period ${ }^{7}$.

However, dengue symptoms are not so similar to covid-19 symptoms ${ }^{8}$. However, some respiratory diseases have similar symptoms of covid-19 infection ${ }^{9}$, in such a way that perhaps it can confuse the diagnosis without precise tests for correct analysis of the contagious virus ${ }^{10}$. In view of this, PAHO, like the Ministry of Health of Brazil, also publishes epidemiological bulletins of infectious diseases, and during SE 9 2020, the detections of influenza A (H1N1 and H3N2) and B decreased compared to the previous week. along with a smaller peak in SE 12, with inter-seasonal levels, culminating 
in a low activity recorded in SE 15, including the respiratory syncytial virus that did not record any records in that period ${ }^{12,13}$.

Given the above, a recent study evaluated the increase in hospitalizations for respiratory viruses, which included influenza $\mathrm{A}(\mathrm{H} 1 \mathrm{~N} 1$ and $\mathrm{H} 3 \mathrm{~N} 2), \mathrm{B}$ and respiratory syncytial virus, in 2020 in Brazil until the epidemiological week 12, concluding that the lack of specific information about the etiological agent of hospitalizations, in addition to the greater number of cases among the elderly during the same period in which there was an increase in contagion due to coronavirus, culminates in the hypothesis that there may be a possible detection of the current pandemic disease (COVID-19) by the system of surveillance of respiratory viruses already known, although it is not possible to prove due to the lack of elaboration of precise statistical calculations ${ }^{14}$, taking into account the lack of an expressive number of specific tests, which could result in a better accuracy of diagnoses and, probably, minimize the effects of the pandemic ${ }^{15}$.

\section{Conclusion}

In terms of problems in diagnoses and test accuracy in parallel to other common viruses in Brazil, such as Dengue and Influenza, there seems to be a correlation, not statistically elaborated, between the fall in the contagion of these diseases and the peak of contamination by COVID-19. What denotes a possible control of the incidence of arboviruses, such as dengue, and of respiratory diseases, such as influenza A, B and respiratory syncytial virus, in parallel to the increase in the number of contaminated by the new coronavirus, or a possible indication of problems to diagnose inpatient screening precisely in the midst of a pandemic panic.

\section{References}

1. Liu Y, Gayle AA, Wilder-Smith A, Rocklöv J. The reproductive number of COVID-19 is higher compared to SARS coronavirus. J Travel Med. 2020;27(2):1-6. doi:10.1093/jtm/taaa021

2. Rodriguez-Morales AJ, Gallego V, Escalera-Antezana JP, et al. COVID-19 in Latin America: The implications of the first confirmed case in Brazil. Travel Med Infect Dis. 2020;(February):101613. doi:10.1016/j.tmaid.2020.101613

3. Brasil M da saude. Boletim epidemiológico 15 - Arboviroses urbanas 2018. In: Vol 49. ; 2018:1-14. 
4. Brasil M da saude. Boletim epidemiológico 15 - Arboviroses urbanas 2019. 2019:1-11.

5. Brasil M da saude. Boletim epidemiológico 15 - Arboviroses urbanas 2020. In: Vol 51. ; 2020.

6. Brasil M da saude. Saúde regulamenta condições de isolamento e quarentena. https://www.saude.gov.br/noticias/agencia-saude/46536-saude-regulamentacondicoes-de-isolamento-e-quarentena. Published 2020. Accessed May 1, 2020.

7. G1. Casos de coronavírus no Brasil em 13 de abril. Secretarias estaduais de saúde contabilizam 23.753 infectados em todos os estados e 1.355 mortos. https://g1.globo.com/bemestar/coronavirus/noticia/2020/04/13/casos-decoronavirus-no-brasil-em-13-de-abril.ghtml. Published 2020. Accessed May 1, 2020.

8. Halstead SB. Dengue. 2007.

9. Investigation O. Clinical Signs and Symptoms Predicting Influenza Infection. 2000;160:3243-3247.

10. Yan CH, Faraji F, Prajapati DP, Boone CE, DeConde AS. Association of chemosensory dysfunction and Covid-19 in patients presenting with influenzalike symptoms. Int Forum Allergy Rhinol. 2020:1-18. doi:10.1002/alr.22579

11. Ceará G do E do. Boletim epidemiológico 11 - SARG e Influenza 2020. 2020;(Quadro 1):1-8.

12. OPAS/WHO. Influenza Report EW 9/ Reporte de Influenza SE 9 - 2020. In: ; 2020:1-40.

13. OPAS/WHO. Influenza Report EW 15/ Reporte de Influenza SE 15 - 2020. In: ; 2020:1-38.

14. Niquini RP, Lana RM. COVID-19 and hospitalizations for SARI in Brazil : a comparison up to the 12th epidemiological week of 2020 COVID-19 e hospitalizações por SRAG no Brasil : uma comparação até a 12 a semana epidemiológica de 2020 COVID-19 y las hospitalizaciones por el SRA. 2020;36(4):1-8. doi:10.1590/0102-311X00070120 
15. Peto J. Covid-19 mass testing facilities could end the epidemic rapidly. BMJ. 2020;368(March):110110. doi:10.1136/bmj.m1163 